\title{
AM Fungi Influences the Photosynthetic Activity, Growth and Antioxidant Enzymes in Allium sativum L. under Salinity Condition
}

\author{
Mahesh BORDE, Mayura DUDHANE, Paramjit Kaur JITE \\ University of Pune, Department of Botany, Pune, 411007, India; paramjit.jite@gmail.com; mmborde@yahoo.co.in
}

\begin{abstract}
Potential of Arbuscular mycorrhizal (AM) fungi in alleviating adverse salt effects on growth was tested in garlic (Allium sativum L.). Towards this objective we analyzed the AM root colonization and the activities of various antioxidant enzymes like peroxidase, catalase, and superoxide dismutase at 0,100, 200 and $300 \mathrm{mM}$ salinity levels. The activities of all the antioxidant enzymes studied were found to be increased in AM garlic plants. Antioxidant activity was maximum in 100 and $200 \mathrm{mM} \mathrm{NaCl}$ (sodium chloride) in AM and non-AM plants. Proline accumulation was induced by salt levels and it was more in leaves as well as roots of AM plants as compared to non-AM plants, this indicating that mycorrhiza reduced salt injury. Growth parameters of garlic plants like leaf area, plant fresh and dry weight and antioxidant enzyme activities were higher at moderate salinity level. This work suggests that the mycorrhiza helps garlic plants to perform better under moderate salinity level by enhancing the antioxidant activity and proline content as compared to non-AM plants.
\end{abstract}

Keywords: Allium sativum, antioxidant enzymes, AM fungi, proline, salt stress

\section{Introduction}

Accumulation of salts on the soil surface is one of the most serious agricultural problems in arid and semiarid regions including India (Akhter, 2004). In India, 7 million hectars of land is saline because of over-irrigation with ground water of high salt content (Bhoopander $\mathrm{et}$ al., 2003). Yearly, more land are rendered unproductive due to accumulation of salt which inhibit crop growth and productivity. A. sativum L. (garlic) is one of the important crops grown on one lac twenty thousand hector area in arid and semiarid regions of India for its bulbs which is an important spice/condiment. For the plant host the cost of AM colonization is the delivery of $4-20 \%$ of photosynthetically fixed carbon to its fungal partner (Wright et al., 1998; Bago et al., 2000). Historically, these costs must have been offset by the benefits to the colonized plant. AM symbiosis is complex biological interactions; their impact varies in different environmental conditions and depends on the specific combination of plant and fungus involved (Johnson et al., 1997; Burleigh et al., 2002; Smith et al., 2003). Consequently, profitable use of AM symbioses in an agricultural context requires the selection of a suitable combination of plant host, fungal partner and agricultural practice to balance costs and benefits. Mycorrhizal colonization in plants involves a number of morphological and biochemical events. In different plant systems, several workers have demonstrated that AM fungi diminish detrimental effects of salinity (Ruiz-Lozano et al., 1996; RuizLozano and Azcon 2000; Al-Karaki and Hammad 2001; Feng et al., 2002).
Several groups of enzymes that may hydrolyze phosphorus esters are commonly called phosphatases (Tabatabai and Bremner, 1969), are present in mature arbuscules and intraradical hyphae of AM fungi (Ezawa et al., 1995; Gianinazzi et al., 1979). Colonization of wheat and onion by various Glomus spp. (including $G$. mosseae) resulted in significant increases in root surface and rhizosphere acid phosphatase activities (Dodd et al., 1987).

Plants under salt stress initiate some defense mechanism to protect themselves from harmful effect of oxidative stress. ROS (Reactive Oxygen Species) scavenging is one such common defense response against abiotic stress (Vranova et al., 2002). During salt stress excessive generation of ROS such as superoxide radical $\left(\mathrm{O}_{2}^{-}\right)$, Hydrogen peroxide $\left(\mathrm{H}_{2} \mathrm{O}_{2}\right)$, hydroxyl radical $\left(\mathrm{OH}^{-}\right)$occurs (Becana, 2000). Generation of these ROS cause rapid cell damage by triggering off a chain reaction (Imlay, 2003) and causes by significant damage to membranes and other essential macromolecules such as photosynthesis, pigments, protein, nucleic acid and lipid (Lin et al., 2000; Foyer et al., 1994).

The major ROS scavenging system includes a complex enzymatic group such as catalase (CAT), peroxidase (POD), superoxide dismutases (SOD), non enzymatic molecules such as (proline, glycine betain, sorbitol, manitol) (Prochazkova et al., 2001). Plants possess an antioxidant defense system, which maintains level of ROS within the cell. SOD catalyses the dismutation reaction of super oxide anion hydrogen peroxide and oxygen. However hydrogen peroxide is toxic to cell and is further detoxified by CAT and POD to water and oxygen. 
Proline is most common osmolyte and osmoprotectant in plants under stress conditions (Hasegawa et al., 2000; MacCue and Hanson, 1990; Serrano and Gaxiola, 1994) which is often considered to be involved in stress resistance mechanisms and osmotic adjustment in stressed tissues of plant (Ashraf and Foolad, 2007). Induced Proline accumulation in AM plant is subjected to drought stress has been reported (Azco'n et al., 1996; Goicoechea et al., 1998). Similar studies were done in Vigna radiate and Vicia faba plant (Jindal et al., 1993; Rabie and Almadina, 2005).

Therefore purpose of the present study is to investigate the role of AM fungal species Glomus fasciculatum (Gf) under salinity stress and its effect on growth enhancement, physiological and biochemical (antioxidant enzymes like CAT, POD, SOD and proline accumulation) parameters in AM garlic (A. sativum L.) as compared to non treated control. Therefore the presence study was undertaken to evaluate protective potential of AM fungi to salt stress on a spice and medicinal important plants of India $A$. sativum L.

\section{Materials and methods}

\section{Plant material and experimental design}

The cloves of garlic (A. sativum L.) local variety Godavari (selection 2) was obtained from National Research Center of Onion and Garlic, Rajgurunagar Maharashtra, India. These were surface sterilized with $0.01 \% \mathrm{HgCl}_{2}$ These clove were grown in plastic bags having size $20 \times 30$ $\mathrm{cm}$. containing $3 \mathrm{~kg}$ of steam sterilized $\left(121^{\circ} \mathrm{C}\right.$ and 103.42 $\mathrm{k}$ pa pressure for $1 \mathrm{~h}$ ) garden sandy loamy soil. Soils were analyzed with respect to: Sand $80 \%$ Silt 15\% and Clay 5\% by website: www.pedosphere.com. The experiments were conducted under natural light and temperature conditions above ground level.

Three month old $30 \mathrm{~g}$ of mycorrhizal inoculum Glomus fasciculatum containing AM colonized roots, rhizosphere soil having extramatrical mycelium and spores (10-15 spores/g of soil) was use for each seedlings. The inoculum was placed five $\mathrm{cm}$. below each clove. Non mycorrhizal garlic plants consisted of same inoculum but autoclaved $\left(100^{\circ} \mathrm{C}, 103.42 \mathrm{k}\right.$ pa pressure for $\left.1 \mathrm{~h}\right)$. The experimental design consisted of Completely Randomized Block design in $2 \times 4$ factorial design with mycorrhizal factor (AM and non $\mathrm{AM})$ and salt factor $(0,100,200$ and $300 \mathrm{mM} \mathrm{NaCl})$ having nine replicates each. The treatments consisted of: (1) non-AM control i.e. zero salinity level and three different $\mathrm{NaCl}$ levels of $100 \mathrm{mM}, 200 \mathrm{mM}$, and $300 \mathrm{mM}$, respectively $(\mathrm{C}, \mathrm{C}+1 \mathrm{~S}, \mathrm{C}+2 \mathrm{~S}, \mathrm{C}+3 \mathrm{~S})$ and $\mathrm{AM}$ inoculated plants with zero salinity level, AM inoculated three different $\mathrm{NaCl}$ levels of $100 \mathrm{mM}, 200 \mathrm{mM}$, and $300 \mathrm{mM}$ (Gf, $\mathrm{Gf}+1 \mathrm{~S}, \mathrm{Gf}+2 \mathrm{~S}, \mathrm{Gf}+3 \mathrm{~S})$ respectively. In each bag three plants were maintained, thirty day old mycorrhizal and non mycorrhizal garlic seedlings were subjected to three different salinity levels by addition of $100 \mathrm{ml}$ solution con- taining $100 \mathrm{mM}, 200 \mathrm{mM}$, and $300 \mathrm{mM}, \mathrm{NaCl}$ to each pot for twice in a week. Thereafter $200 \mathrm{ml}$ of water was added two days of interval.

\section{Growth measurement and biochemical analysis}

Plants were harvested after 45 and 75 days of AM inoculation and analyzed for morphological parameters such as leaf area, total biomass, percent root colonization, mycorrhizal dependency and tolerance indices. At each salinity level, the mycorrhizal dependency (M.D.) of the plant was calculated according to Gerdemann (1975), as:

M.D. $=\frac{\text { Dry weight of AM plant a ta particular level of salinity }}{\text { Dry weight of non - A M plant a t the same level of salinity }} \times 100$

\section{AM colonization}

The percentage of AM colonization in roots was analyzed by clearing and staining of roots by the method (Phillips and Haymans, 1970) method and percent AM colonization in root was determined by gridline intersect method Giovannetti and Mosse (1980). Proline was determined by (Bates et al., 1973). Proline content was expressed as $\mu \mathrm{mol}$ proline/g of tissue.

\section{Relative water content (Barr et al., 1962)}

Leaf was cut in to $5-10 \mathrm{~cm}^{2}$, and then weighed immediately to record fresh weight. Leaf sample was floated in deionized water in Petri dish for 4 hours at normal room temperature and light. After 4 hours, the sample was taken out from water, and surface water was removed and again weighed to obtain fully turgid weight. Sample was dried in an oven at $80^{\circ} \mathrm{C}$ for 24 hours weighed again.

Formula: RWC $(\%)=[($ Fresh wt.-dry wt. $) /$ turgid wt.dry wt.)] x 100.

\section{Physiological and biochemical parameters}

Chlorophyll content was determined by method Arnon (1949), Acid and alkaline phosphatase was measured by the method of Lowry et al. (1954).

\section{Antioxidant enzyme activity assay}

Enzyme extracts were prepared in extraction buffer Enzyme extracts were prepared in extraction buffer containing $1 \mathrm{M}$ Tris-acetate buffer ( $\mathrm{pH}$ 6.0), 0.5 M EDTA.Na2 ( $\mathrm{pH}$ 8.0), $2 \% \mathrm{w} / \mathrm{v}$ PVP, $0.1 \mathrm{mM}$ PMSF, $0.2 \% \mathrm{v} / \mathrm{v}$ Triton $\mathrm{x}$ 100 by grinding $0.5 \mathrm{~g}$ leaf or root sample in $5 \mathrm{ml}$ extraction buffer. Extracts were centrifuged at $10,000 \mathrm{xg}$ at $4^{\circ} \mathrm{C}$ for $10 \mathrm{~min}$, and the supernatant was used as source of enzyme. Every assay was conducted three times. SOD activity was determined by Beauchamp and Fridovich (1971) method. SOD activity was expressed in units. One unit $(\mathrm{U})$ is defined as the amount of change in absorbance by unit $\mathrm{h}^{-1}$ $\mathrm{mg}^{-1}$ protein. Guiacol POD was assayed by Putter's (1974) method. The POD activity was expressed in unit per mg of protein. CAT activity was measured by Aebi's method 
66

(1984). The enzyme activity was expressed in $\mathrm{U}_{\mu \mathrm{g}}{ }^{-1}$ protein $\left(\mathrm{U}=1 \mathrm{mM}\right.$ of $\mathrm{H}_{2} \mathrm{O}_{2}$ reduction $\mathrm{min}^{-1} \mathrm{ug}^{-1}$ protein). The protein content was determined using Bradford's method (1979). Proline content was estimated by method (Bates et al., 1973), Absorbance was read at $520 \mathrm{~nm}$. Proline content was expressed as $\mu \mathrm{mol}$ proline/gm of tissue.

\section{Statistical analysis}

Data were analyzed by One Way ANOVA followed by Duncan's multiple new range test and different small bold alphabetical letters indicate significant differences at $\mathrm{p}<0.05$ level.

\section{Results and discussion}

After 75 days of AM inoculation and after stress recovery mycorrhizal garlic plants at second level of salinity showed significant increase in leaf area (Tab. 1). After 45 and 75 days of AM inoculation in first and second level of salinity stressed mycorrhizal garlic plants showed more plant fresh weight as compared to non mycorrhizal garlic plants. Increase in morphological parameters in AM garlic plants during moderate salinity condition was observed which states that mycorrhiza helps garlic plants to survive luxuriantly under saline conditions. Many studies have indicated that inoculation with AM fungi improves growth of plant under salt stress condition (Yano et al., 2003; Giri and Mukerji, 2004; Cho et al., 2006; Ghazi Al-
Karaki, 2006). After 45 and 75 days of AM inoculation, dry weight in mycorrhizal garlic plants at second level of salinity level was found to increase significantly as compared to non mycorrhizal garlic plants. The higher biomass in moderately saline condition by Glomus mosseae inoculated with tomato plants showed similar results (Ghazi Al-Karaki, 2001). Thus, mycorrhizal fungi improve plant growth under salt stress condition (Al-Karaki, 2000; Centrell and Lindermann, 2001).

After 45 days of AM inoculation, mycorrhizal garlic plants in second and third level of salinity showed significant increase in relative water content as compared to non mycorrhizal garlic plants. After stress recovery mycorrhizal garlic plants in non stressed condition was found to increase significantly in relative water content as compared to non mycorrhizal garlic plants (Tab. 2).

Proline is an important organic compound that participates in osmotic adjustment (Morgan, 1984; Kishor et al., 1995). Proline act as a major reservoir of energy and nitrogen for utilization during salinity stress (Goas et al., 1982). After 45 days of AM inoculation the shoot proline accumulation was found to increase significantly in mycorrhizal garlic plants at first and second level of salinity levels as compared to non mycorrhizal garlic plants. After 75 days of AM inoculation the shoot proline accumulation in non-mycorrhizal garlic plants increased significantly as compared to mycorrhizal garlic plants at first second and third level of salinity stress. Proline is accumu-

Tab. 1. Morphological parameters in Allium sativum L. after 45 and 75 days of AM treatment under non- salinity and salinity conditions

\begin{tabular}{ccccccc}
\hline \multirow{2}{*}{ Treatments } & \multicolumn{2}{c}{ Leaf area $\left(\mathrm{cm}^{2}\right)$} & \multicolumn{2}{c}{ Fresh weight $(\mathrm{g})$} & \multicolumn{2}{c}{ Dry weight $(\mathrm{g})$} \\
\cline { 2 - 7 } & 45 days & 75 days & 45 days & 75 days & 45 days & 75 days \\
\hline C & $8.750 \pm 1.670 \mathrm{ab}$ & $10.417 \pm 1.160 \mathrm{abc}$ & $1.40 \pm 0.31 \mathrm{ab}$ & $1.42 \pm 0.09 \mathrm{a}$ & $0.263 \pm 0.10 \mathrm{ab}$ & $0.274 \pm 0.03 \mathrm{ab}$ \\
$\mathrm{C}+1 \mathrm{~S}$ & $8.700 \pm 0.668 \mathrm{ab}$ & $9.033 \pm 0.731 \mathrm{abcd}$ & $1.34 \pm 0.53 \mathrm{ab}$ & $1.26 \pm 0.26 \mathrm{a}$ & $0.164 \pm 0.09 \mathrm{ab}$ & $0.247 \pm 0.01 \mathrm{ab}$ \\
$\mathrm{C}+2 \mathrm{~S}$ & $6.163 \pm 1.165 \mathrm{ab}$ & $7.163 \pm 0.954 \mathrm{~cd}$ & $1.33 \pm 0.22 \mathrm{ab}$ & $0.98 \pm 0.29 \mathrm{a}$ & $0.170 \pm 0.05 \mathrm{~b}$ & $0.234 \pm 0.05 \mathrm{ab}$ \\
$\mathrm{C}+3 \mathrm{~S}$ & $4.550 \pm 0.831 \mathrm{~b}$ & $5.550 \pm 0.686 \mathrm{~d}$ & $1.22 \pm 0.54 \mathrm{~b}$ & $0.95 \pm 0.13 \mathrm{a}$ & $0.169 \pm 0.04 \mathrm{~b}$ & $0.202 \pm 0.01 \mathrm{ab}$ \\
Gf & $8.636 \pm 1.867 \mathrm{ab}$ & $11.303 \pm 1.360 \mathrm{ab}$ & $1.53 \pm 0.29 \mathrm{ab}$ & $1.52 \pm 0.47 \mathrm{a}$ & $0.249 \pm 0.01 \mathrm{ab}$ & $0.365 \pm 0.10 \mathrm{ab}$ \\
Gf $+1 S$ & $11.027 \pm 5.012 \mathrm{a}$ & $12.360 \pm 3.149 \mathrm{a}$ & $1.71 \pm 0.23 \mathrm{ab}$ & $1.49 \pm 0.17 \mathrm{a}$ & $0.317 \pm 0.03 \mathrm{ab}$ & $0.334 \pm 0.04 \mathrm{ab}$ \\
Gf $+2 \mathrm{~S}$ & $9.000 \pm 1.632 \mathrm{ab}$ & $10.666 \pm 1.699 \mathrm{abc}$ & $2.13 \pm 0.43 \mathrm{a}$ & $1.50 \pm 0.25 \mathrm{a}$ & $0.383 \pm 0.08 \mathrm{a}$ & $0.378 \pm 0.13 \mathrm{a}$ \\
Gf $+3 \mathrm{~S}$ & $6.996 \pm 2.372 \mathrm{ab}$ & $8.330 \pm 1.439 \mathrm{bcd}$ & $1.43 \pm 0.08 \mathrm{ab}$ & $0.87 \pm 0.36 \mathrm{a}$ & $0.279 \pm 0.05 \mathrm{ab}$ & $0.260 \pm 0.09 \mathrm{~b}$ \\
\hline
\end{tabular}

Tab. 2. Relative water content, shoot and root proline accumulation in Allium sativum L. after 45 and 75 days of AM treatment under non-salinity and salinity conditions

\begin{tabular}{|c|c|c|c|c|c|c|}
\hline \multirow{3}{*}{ Treatments } & \multirow{2}{*}{\multicolumn{2}{|c|}{ Relative water content (\%) }} & \multicolumn{4}{|c|}{ Proline (u mole/g of tissue $\times 10^{-3}$ ) } \\
\hline & & & \multicolumn{2}{|c|}{ Shoot } & \multicolumn{2}{|c|}{ Root } \\
\hline & 45 days & 75 days & 45 days & 75 days & 45 days & 75 days \\
\hline C & $81.225 \pm 7.017 \mathrm{abc}$ & $77.981 \pm 14.712 \mathrm{a}$ & $1.442 \pm 0.150 \mathrm{~d}$ & $3.737 \pm 0.181 f$ & $1.206 \pm 0.110 \mathrm{c}$ & $4.855 \pm 0.216 \mathrm{c}$ \\
\hline $\mathrm{C}+1 \mathrm{~S}$ & $81.023 \pm 10.607 \mathrm{abc}$ & $85.611 \pm 13.251 \mathrm{a}$ & $2.030 \pm 0.190 \mathrm{~d}$ & $4.944 \pm 0.144 \mathrm{de}$ & $2.383 \pm 0.360 \mathrm{~b}$ & $6.827 \pm 0.150 \mathrm{~b}$ \\
\hline $\mathrm{C}+2 \mathrm{~S}$ & $74.621 \pm 16.937 \mathrm{bc}$ & $72.574 \pm 13.100 \mathrm{a}$ & $5.326 \pm 0.409 b$ & $4.620 \pm 0.150 \mathrm{e}$ & $2.266 \pm 0.150 \mathrm{~b}$ & $6.621 \pm 0.144 b$ \\
\hline $\mathrm{C}+3 \mathrm{~S}$ & $70.047 \pm 14.250 \mathrm{c}$ & $76.799 \pm 6.3355 \mathrm{a}$ & $5.356 \pm 0.041 b$ & $5.120 \pm 0.190 \mathrm{~d}$ & $2.442 \pm 0.110 \mathrm{~b}$ & $7.357 \pm 0.978 b$ \\
\hline Gf & $92.790 \pm 14.298 \mathrm{ab}$ & $94.188 \pm 29.595 a$ & $1.706 \pm 0.150 \mathrm{~d}$ & $4.090 \pm 0.110 \mathrm{f}$ & $1.530 \pm 0.340 \mathrm{c}$ & $9.093 \pm 0.314 \mathrm{a}$ \\
\hline $\mathrm{Gf}+1 \mathrm{~S}$ & $98.204 \pm 4.1616 \mathrm{a}$ & $90.429 \pm 6.0914 \mathrm{a}$ & $2.678 \pm 0.397 \mathrm{c}$ & $6.739 \pm 0.272 \mathrm{a}$ & $2.648 \pm 0.144 \mathrm{~b}$ & $9.270 \pm 0.563 \mathrm{a}$ \\
\hline $\mathrm{Gf}+2 \mathrm{~S}$ & $96.124 \pm 4.1414 \mathrm{a}$ & $93.446 \pm 13.688 \mathrm{a}$ & $7.239 \pm 0.381 \mathrm{a}$ & $5.944 \pm 0.150 \mathrm{~b}$ & $4.149 \pm 0.438 \mathrm{a}$ & $10.123 \pm 0.61 \mathrm{a}$ \\
\hline $\mathrm{Gf}+3 \mathrm{~S}$ & $91.929 \pm 16.073 \mathrm{ab}$ & $80.044 \pm 5.5963 \mathrm{a}$ & $5.297 \pm 0.401 \mathrm{~b}$ & $5.120 \pm 0.190 \mathrm{c}$ & $4.267 \pm 0.479 \mathrm{a}$ & $9.829 \pm 0.166 \mathrm{a}$ \\
\hline
\end{tabular}


lated in shoots and enhances osmotic adjustment. Proline accumulation was more in shoots of AM garlic plant than shoots of non-AM garlic plants. In roots, proline accumulation after 45 days of AM inoculation was found to significantly increase in mycorrhizal garlic plants at second and third salinity level as compared to non mycorrhizal garlic plants. Proline accumulation in roots was found to increase as compared to shoots, except in second levels of salinity treated non mycorrhizal shoot, this higher proline accumulation in roots as compared to shoot may be due to the fact that the roots are the primary site for saline stress and the mycorrhiza colonized in roots may have induced accumulation of proline and other antioxidant enzymes in roots.

After 45 days of AM inoculation, mycorrhizal dependency in AM treated garlic plants during first second and third level of salinity stress was $203.77 \%, 233.84 \%$ and $168.77 \%$ respectively. After 75 days of AM inoculation, mycorrhizal dependency in AM treated garlic plants during first second and third level of salinity stress was $136.65 \%, 169.67 \%$ and $128.53 \%$ respectively. After 45 and 75 days of AM inoculation mycorrhizal garlic plants in second salinity level showed more tolerance to salinity stress as compared to non mycorrhizal garlic plants. Thus increment in mycorrhizal dependency could be concluded that the benefits symbiotic association between AM fungi and garlic plants increased under salinity conditions. Mycorrhizal dependency in lower and moderate saline conditions was higher, but in higher saline condition it went on decreasing, hence we concluded that at first and second level of salinity conditions mycorrhiza help not only for acclimatization but also for continued nutrient uptake during progressive growth stages in garlic plants. Mycorrhizal garlic plants were found to be more tolerant in second level of salinity stress condition because mycorrhizal inoculation protects the plants against the detrimental effect of salt, which may be due to the root development

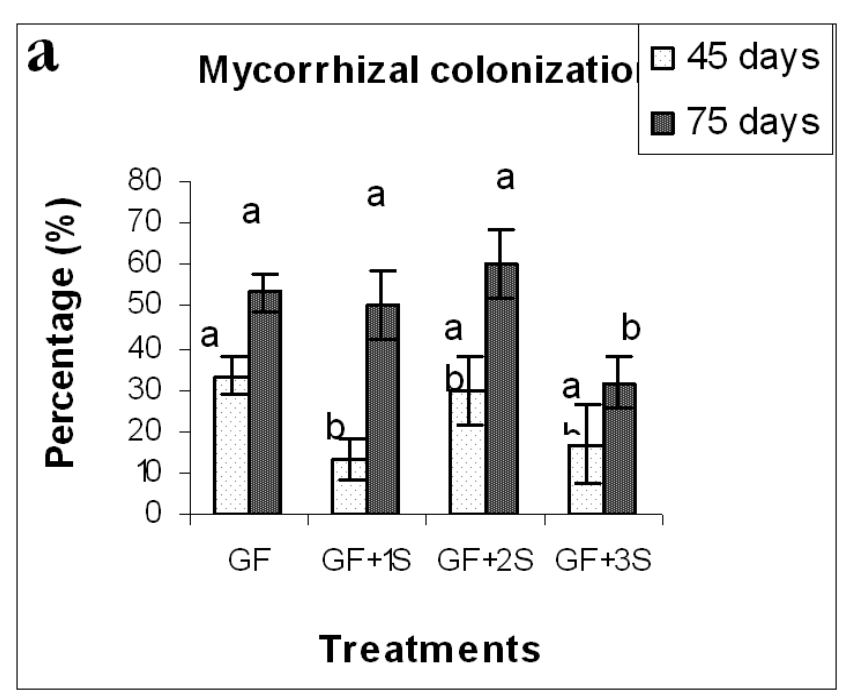

higher nutrient acquisition in response to AMF colonization was suggested to be a plant strategy for salt stress tolerance (Poss et al., 1985).

As shown in Fig. 1a, after 45 days of AM inoculation, the mycorrhizal non-stressed garlic roots showed 33.33\% AM colonization, during saline conditions the AM colonization was higher in second level of salinity $(30 \%)$ treated garlic plants than first and third level of salinity (13.33 and $16.66 \%$ ) treated garlic plants. But after 75 days of AM inoculation, second level of salinity treated garlic plants showed $60 \%$ AM colonization which was higher than other salinity treatments. That means at second salinity level the percent root colonization increased and at third salinity level it was found to be inhibited. Similar results were obtained by Copwann et al. (1996) and Rosendal et al. (1991).

The plant is stimulated by colonization to a limitation of $\mathrm{Na}$ transport towards the leaves, and leads to better functioning of chloroplast and photosynthetic efficiency, as shown by Al-Karaki (2000) and Rabie (2005). Our results indicated that after 45 and 75 days of AM inoculation in all salinity levels, mycorrhizal garlic plants showed higher chlorophyll content as compared to non mycorrhizal garlic plants (Fig. 1b). Thus, AM symbiosis could enhanced the photosynthetic ability of garlic leaves, which was in agreement with the results of other studies (Giri and Mukerji, 2004; Sannazzaro et al., 2006; Colla et al., 2008, Sheng et al., 2008).

Phosphatases of mycorrhizae are both specifically induced in the presence of Glomus spores and are sensitive to the levels of phosphate in the environment (Pacovsky et al., 1991). MacDonald and Lewis (1978) cytochemically demonstrated the presence of acid phosphatase in G. mosseae. In our experiment after 75 days of AM inoculation acid and alkaline phosphatase activities significantly increased in mycorrhiza inoculated garlic plant as compared to non mycorrhizal garlic plants. In second level of salin-

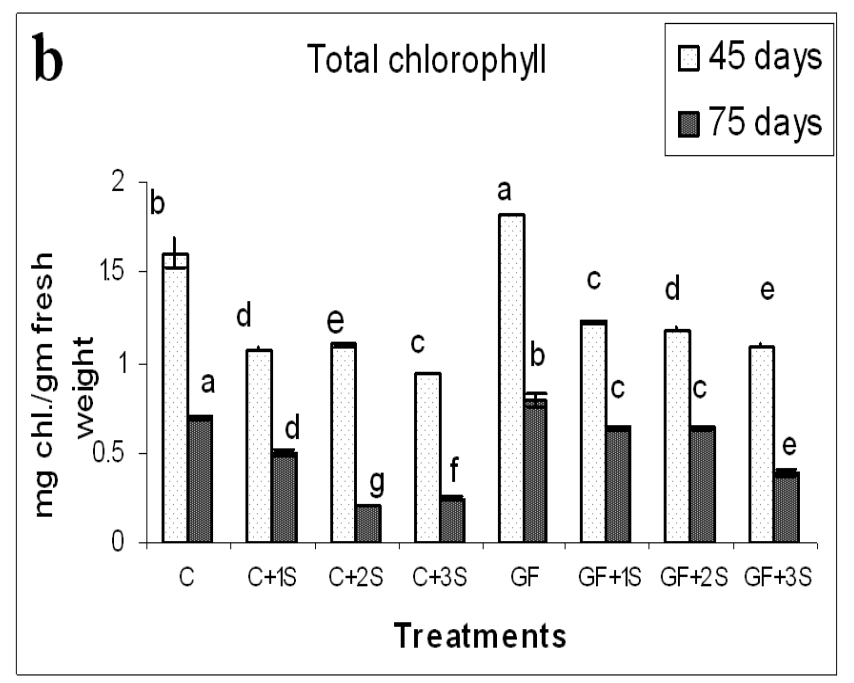

Fig. 1. Percentage of AM colonization and Chlorophyll content of Allium sativum L. after 45 and 75 days of AM treatment 
68

Tab. 3. Acid and Alkaline phosphatase activity in Allium sativum L. after 45 and 75 days of AM treatment under non- salinity and salinity conditions

\begin{tabular}{|c|c|c|c|c|}
\hline \multirow[t]{2}{*}{ Treatments } & \multicolumn{2}{|c|}{$\begin{array}{c}\text { Acid Phosphatase } \\
\mu \text { mole pnp-release/g fresh wt. }\end{array}$} & \multicolumn{2}{|c|}{$\begin{array}{c}\text { Alkaline Phosphatase } \\
\text { umole pnp-release/g fresh wt. }\end{array}$} \\
\hline & 45 days & 75 days & 45 days & 75 days \\
\hline $\mathrm{C}$ & $3.837 \pm 0.462 \mathrm{a}$ & $4.071 \pm 0.018 \mathrm{e}$ & $1.249 \pm 0.053 \mathrm{a}$ & $3.958 \pm 0.028 \mathrm{c}$ \\
\hline $\mathrm{C}+1 \mathrm{~S}$ & $4.120 \pm 0.364 \mathrm{a}$ & $3.909 \pm 0.033 \mathrm{f}$ & $1.228 \pm 0.106 \mathrm{a}$ & $3.184 \pm 0.028 \mathrm{f}$ \\
\hline $\mathrm{C}+2 \mathrm{~S}$ & $3.919 \pm 0.405 \mathrm{a}$ & $3.755 \pm 0.057 \mathrm{~g}$ & $1.184 \pm 0.069 \mathrm{ab}$ & $4.007 \pm 0.022 \mathrm{c}$ \\
\hline $\mathrm{C}+3 \mathrm{~S}$ & $3.763 \pm 0.600 \mathrm{a}$ & $3.621 \pm 0.022 \mathrm{~h}$ & $1.079 \pm 0.089 \mathrm{~b}$ & $3.950 \pm 0.032 \mathrm{c}$ \\
\hline Gf & $3.997 \pm 0.439 \mathrm{a}$ & $4.218 \pm 0.039 \mathrm{~d}$ & $1.228 \pm 0.015 \mathrm{a}$ & $4.333 \pm 0.028 \mathrm{~b}$ \\
\hline $\mathrm{Gf}+1 \mathrm{~S}$ & $4.184 \pm 0.064 \mathrm{a}$ & $4.845 \pm 0.025 b$ & $1.197 \pm 0.035 \mathrm{ab}$ & $3.668 \pm 0.052 \mathrm{e}$ \\
\hline $\mathrm{Gf}+2 \mathrm{~S}$ & $4.223 \pm 0.015 \mathrm{a}$ & $5.097 \pm 0.047 \mathrm{a}$ & $1.282 \pm 0.057 \mathrm{a}$ & $4.644 \pm 0.050 \mathrm{a}$ \\
\hline $\mathrm{Gf}+3 \mathrm{~S}$ & $4.220 \pm 0.014 \mathrm{a}$ & $4.714 \pm 0.040 \mathrm{c}$ & $1.269 \pm 0.022 \mathrm{a}$ & $3.822 \pm 0.022 \mathrm{~d}$ \\
\hline
\end{tabular}
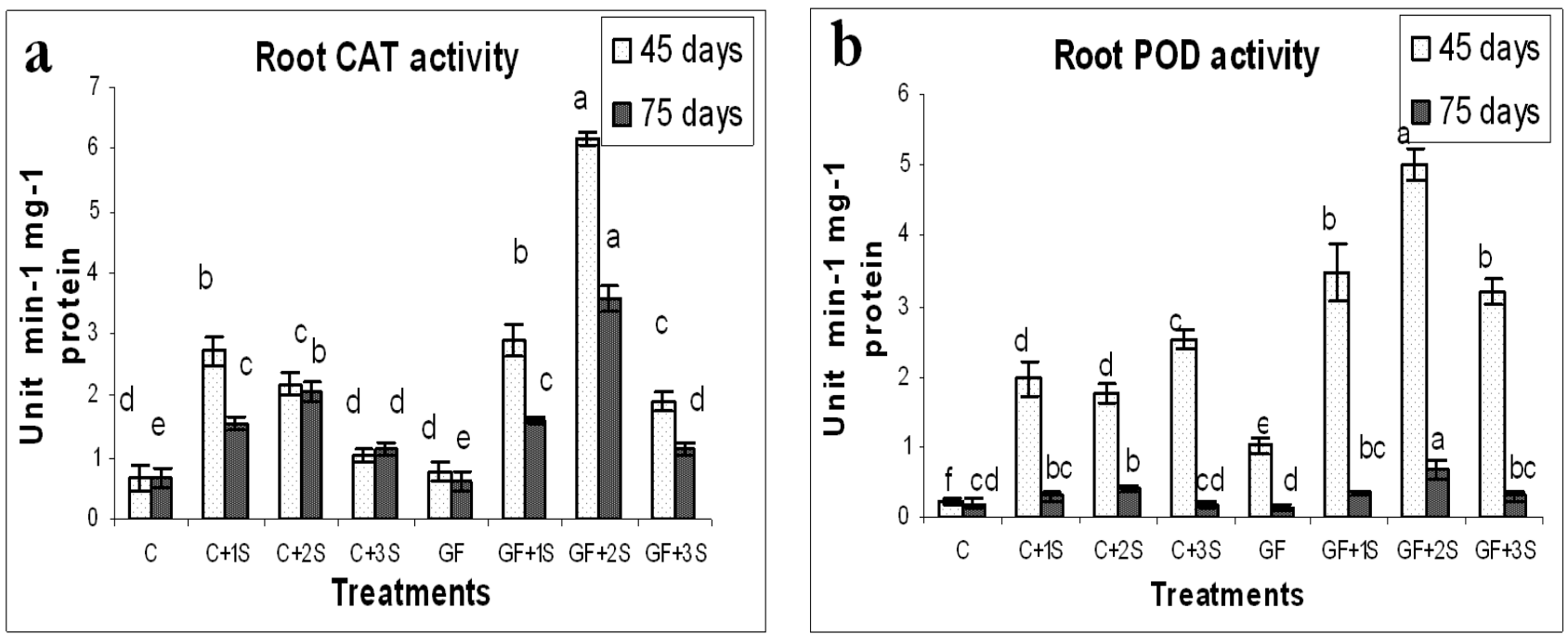

Fig. 2. CAT and POD activity from roots of Allium sativum L. after 45 and 75 days of AM treatment

ity stressed mycorrhizal garlic plants, phosphatase activity was much higher (Tab. 3). This increase in activity was positively correlated to phosphate uptake by mycorrhizal garlic plants under salinity conditions.

Cells under salt stress initially accumulate salts as free osmotica; however, a toxic specific ion effect appears after a certain threshold salt level. An excess of these ions may alter membrane integrity, enzymatic activity, protein and nucleic acid metabolism (Hasegawa et al., 2000; Mansour and Salama, 2005). The production of toxic oxygen derivatives increased in biotic and abiotic stresses. Plants possess efficient scavenging system of ROS that protect them from oxidative damage (Foyer et al., 1994). As a part of this system antioxidant enzymes are key elements in defense mechanism. The activity of antioxidant enzymes has been reported to increase under saline conditions in the case of salt tolerant cotton (Meloni et al., 2003). As shown in Fig. 2a, after 45 days of AM inoculation, induced CAT activity in all treatment After 45 days of AM inoculation, CAT activity was to be higher $(6.10 \%, 179.8 \%$ and $87.15 \%)$ in mycorrhizal than non mycorrhizal garlic plants at first second and third level of salinity treatments and declined after 75 days of AM inoculation. After 75 days of AM in- oculation, the CAT activity was higher (3.00, 73.39 and $2.32 \%)$ than non mycorrhizal garlic plants at first second and third level of salinity treatments. The CAT activity in roots of non mycorrhizal garlic plant increased in $100 \mathrm{mM}$ and $200 \mathrm{mM} \mathrm{NaCl}$ treatments, but at higher salinity level, CAT activity was found to decrease. The overall CAT activity was observed to be more in mycorrhizal garlic plants than non mycorrhizal garlic plants in first and second level of salinity treatment.

As shown in Fig. 2b, after 45 days of AM inoculation the POD activity was higher (76.29\%, 184.76\% and $26.84 \%)$ in AM inoculated garlic plants as compared to non mycorrhizal garlic plants at first second and third level of salinity conditions. POD activity was highly induced in mycorrhizal garlic plants in 100 and $200 \mathrm{mM}$ $\mathrm{NaCl}$ stress. After 75 days of AM inoculation, POD activity in mycorrhiza inoculated garlic plants was significantly higher $(10.96 \%, 62.60 \%$ and $59.79 \%)$ as compared to non mycorrhizal garlic plants at first second and third level of salinity respectively. But in comparison with the early stage of salt stress, POD activity was found to reduce in later stage of salt stress especially in third level of salinity stress. The CAT, POD activities were largely induced in 


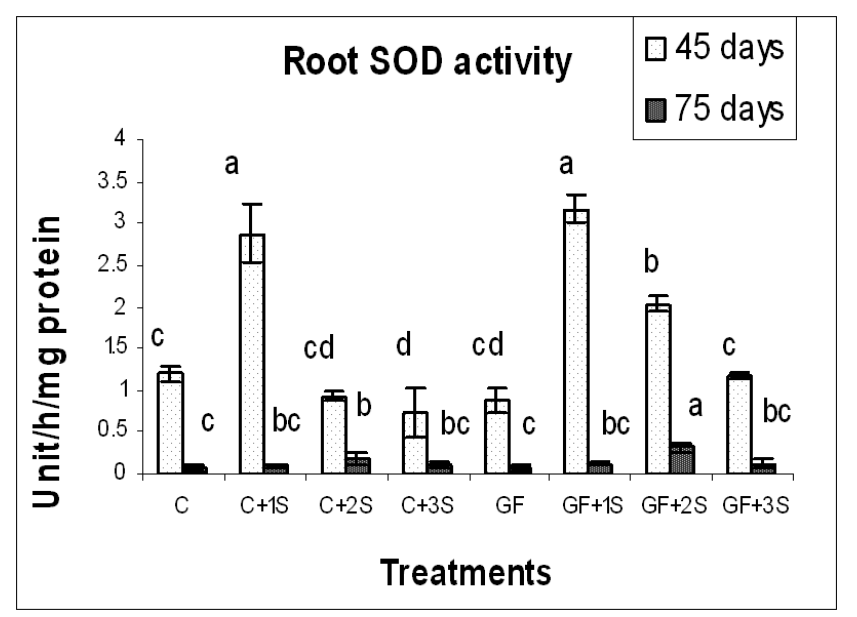

Fig. 3. SOD activity from roots of Allium sativum L. after 45 and 75 days of $A M$ treatment

salinity conditions and were found to be higher in AM treated garlic plants than non-AM plants. The level of antioxidant response depends on species, development and metabolic state of plant as well as duration and intensity of stress (Reddy et al., 2004). Salinity stress increased the antioxidant mechanism in root which is the immediate organ to suffer from salinity more efficiently than leaves.

As shown in Fig. 3, Mycorrhizal garlic plants showed higher SOD activity as compared to non mycorrhizal garlic plants in all treatments. After 45 days of AM inoculation the SOD activity was $(10.49 \%, 118.86 \%$ and $59.32 \%$ ) in mycorrhizal garlic plants as compared to nonmycorrhizal inoculated garlic plants at first second and third level of salinity respectively. After 75 days of AM inoculation, SOD activity of AM inoculated garlic plants was significantly higher $(17.17 \%, 61.90 \%$ and $12.13 \%)$ as compared to non mycorrhizal garlic plants at first second and third level of salinity. But in comparison with the early stages of salt stress the effect of AM and also SOD activity reduced during later stages of salt stress especially in third level of salinity stress. In the experiment, SOD activity was largely induced by AM fungi in saline and non saline conditions, $S O D$ play important role in detoxification of active oxygen species $\left(\mathrm{O}_{2}^{-}\right)$to $\mathrm{O}_{2}$ and $\mathrm{H}_{2} \mathrm{O}_{2}$ mostly in biotic and abiotic stresses. The SOD activity was found to decline after long periods of salt stress which might be the result of adaptation to salt stress. In lettuce (Lactuca sativa) plant colonized by Glomus mosseae and Glomus deserticola under drought stress condition the SOD activities were reported to be higher (Porcel, 2003).

The increased activity of antioxidant enzymes under salt stress is often related to the enhanced tolerance to stress. Acevedo et al. (2001) showed that rapid and continued increased in CAT activity might indicate that CAT is a major enzyme detoxifying hydrogen peroxide in barley under salt stress, since ROS produced through multiple pathways including SOD, under salt stress leads to an overall two fold increase in CAT activity than SOD could better contribute in maintaining steady state level of cellular hydrogen peroxide. Oxidative burst was found to be lower in mycorrhizal garlic plants than non-mycorrhizal garlic plants ultimately led to maintaining cell membrane osmosis. Similar results have been reported from tomato i.e. by enhancing antioxidant enzyme activity and cell membrane osmosis under salt stress, there is an improvement to salt resistance in mycorrhizal plants (He Zhong Qun et al., 2007).

AM colonization is often found to be inhibited during salt stress which was reported by Copwann et al. (1996) and Rosendal et al. (1991). Our results suggested that the POD, CAT and SOD activities were associated with mycorrhizal colonization and increasing level of antioxidant enzymes led to enhanced tolerance of AM Garlic plants to salt stress.

\section{Conclusions}

Inoculation of $G$. fasciculatum was found to be more promising to induce growth of garlic plants under lower and moderate salinity levels. Mycorrhiza protects the plants from salinity injury by increasing biomass content, photosynthetic activity and phosphatase activity by enhancing nutrient status. This study also states that AM fungi helps in increment of antioxidant enzymes CAT, POD, SOD plays an important role in regulation of growth for positive adaptation of AM garlic plants to salt stress. So the strategy of application of mycorrhizal species $G$. fasciculatum as a biofertilizers to garlic crop by enhancing yield of garlic crop cultivated in saline soil areas.

\section{References}

Acevedo, A., A. D. Paleo and M. L. Federico (2001). Catalase deficiency reduces survival and pleiotropically affects agronomic performance in field-grown barley progeny. Plant Sci. 160:847-855.

Aebi, H. (1984). Catalase in vitro. Methods in Enzymo. 105:121-126.

Akhter, J., R. Murray, K. Mahmood, K. A. Malik and S. Ahmed (2004). Improvement of degraded physical properties of a saline-sodic soil by reclamation with kallar grass (Leptochloa fusca). Plant Soil. 258:207-216.

Al-Karaki, G. N. (2000). Growth and mineral acquisition by mycorrhizal tomato grown under salt stress. Mycorrhiza 10:51-54.

Arnon, D. J. (1949). Copper enzymes in isolated chloroplasts. J. of Plant and Cell Physiol. 4:29-30.

Ashraf, M. and M. R. Foolad (2007). Roles of glycine betaine and Proline in improving plant abiotic stress resistance. Environ and Exp Bot. 59(2):206-216.

Azcon, R., M. Gomez and R. M. Tobar (1996). Physiological and nutritional responses by Lactuca sativa to nitrogen 
70

sources and Mycorrhizal fungi under drought. Biol and Fert of Soils. 22:156-161.

Bago, B., P. E. Pfeffer and Y. Shachar-Hill (2000). Carbon metabolism and transport in arbuscular mycorrhizas. Plant Physiol. 124:949-958.

Barr, H. D. and P. E. Weatherley (1962). A re-examination of the relative turgidity technique for estimating water deficit in leaves. Aust. J. of Biol. Sci. 15:413-428.

Bates, L. S., R. P. Waldren and L. D. Teare (1973). Rapid determination of free Proline for water stress studies. Short Communication Plant Soil. 39:205-207.

Becana, M., D. A. Dalton, J. F. Moran, O. I. Iturbe, M. A. Matamoros and M. C. Rubio (2000). Reactive oxygen species and antioxidants in legume nodules. Physiol of Plant. 109:372-381.

Beauchamp, C. and I. Fridovich (1971). Superoxide dismutase: improved assays and an assay applicable to acrylamide gels. Anal Biochem. 44:276-286.

Bhoopander, G., R. Kapoor and K. G. Mukerji (2003). Influence of arbuscular mycorrhizal fungi and salinity on growth, biomass, and mineral nutrition of Acacia auriculiformis. Biol. and Fert. of Soils 38:170-175.

Bradford, M. M. (1976). A rapid and sensitive method for the quantification of microgram quantities of protein utilizing the principle of protein-dye binding. Anal Biochem. 72:248254.

Burleigh, S. H., T. Cavagnaro and I. Jacobson (2002). Functional diversity of arbuscular mycorrhizas extends to the expression of plant genes involved in P nutrition. J. Exp. Bot. 53:15931601.

Cantrell, I. C. and R. G. Linderman (2001). Pre-inoculation of lettuce and onion with VA mycorrhizal fungi reduces deleterious effects of soil salinity. Plant Soil 233:269-281.

Cho, K., H. Toler, J. Lee, B. Ownley, J. C. Stutz and J. L. Moore (2006). Mycorrhizal symbiosis and response of sorghum plants to combined drought and salinity stresses. J. of P Physiol. 163:517-528.

Colla, G., Y. Rouphael, M. Cardarelli, M. Tullio, C. M. Rivera, and E. Rea (2008). Alleviation of salt stress by arbuscular mycorrhizal in zucchini plants grown at low and high phosphorus concentration. Biol. and Fert. of Soil 44:501509.

Copwann, R. H., C. A. Martin and J. C. Stutz (1996). Tomato growth in response to salinity and mycorrhizal fungi from saline or non saline soil. Hort. Sci. 31:313-318.

Dodd, J. C., C. C. Burton, R. G. Burns and P. Jeffries (1987). Phosphatase activity associated with the roots and rhizosphere of plants infected with vesicular-arbuscular mycorrhizal fungi. New Phytol. 107:163-172.

Ezawa, T., M. Saito and T. Yoshida (1995). Comparison of phosphatase localization in the intraradical hyphae of arbuscular mycorrhizal fungi Glomus spp. and Gigaspora spp. Plant Soil 176:57-63.
Feng, G., F. S. Zhang, X. L. Li, C. Y. Tian, C. Tang and Z. Rengel (2002). Improved tolerance of maize plants to salt stress by arbuscular mycorrhiza is related to higher accumulation of soluble sugars in roots. Mycorrhiza 12:185-190.

Foyer, C., H. M. Lelandais and K. J. Kunert (1994). Photooxidative stress in plants. Physiol. Planta 92:696-717.

Gerdemann, J. W. (1975). Vesicular arbuscular mycorrhizal, pp. 575-591. In: D. G. Torrey and D. T. C Clarkson (Eds.). The development and Function of roots. Academic press Lond.

Ghazi, J. and G. N. Al-Karaki (2001). Mycorrhizal influence on fruit yield and mineral content of tomato grown under salt stress. Jof Plant Nutr. 24(8), 1311-1323.

Ghazi, J. and G. N. Al-Karaki (2006). Nursery inoculation of tomato with arbuscular mycorrhizal fungi and subsequent performance under irrigation with saline water. Scien. Horti. 109:1-7.

Gianinazzi, S., V. Gianinazzi-Pearson and J. Dexheimer (1979). Enzymatic studies on the metabolism of vesicular-arbuscular mycorrhiza. III. Ultrastructural localization of acid and alkaline phosphatase in onion roots infected by Glomus mosseae (Nicol. and Gerd.). New Phytol. 82:127-137.

Giovannetti, M. and B. Mosse (1980). An evaluation of techniques for measuring vesicular arbuscular mycorrhizal infection in roots. New Phytol. 84:489-500.

Giri, B. and K. G. Mukerji (2004). Mycorrhizal inoculant alleviates salt stress in Sesbania aegyptiaca and Sesbania grandiflora under field conditions: evidence for reduced sodium and improved magnesium uptake. Mycorrhiza 14:307-12.

Goas, G., M. Goas and F. Larher (1982). Accumulation of free praline and glycine betaine in Aster tripolium subjected to a saline shock: a kinetic study related to light period. Physiol. Plant. 55:383-388.

Goicoechea, N., G. Szalai, M. C. Antolin, M. Sanchez-Diaz and E. Paldi (1998). Influence of arbuscular Mycorrhizae and Rhizobium on free polyamines and Proline levels in waterstressed alfalfa. J. of Plant Physiol. 153:706-711.

Hasegawa, P. M., R. A. Bressan, J. K. Zhu and J. K. Bohnert (2000). Plant cellular and molecular response to high salinity. Ann Rev of Plant Physiol and Plant Mole Biol. 51:463-499.

Imlay, J. A. (2003). Pathways of oxidative damage. Ann. Rev. of Microbiol. 57:395-418.

Jindal, V., A. Atwala, B. S. Sekhon and R. Singh (1993). Effect of vesicular-arbuscular mycorrhizae on metabolism of moong plants under $\mathrm{NaCl}$ salinity. Plant Physiol and Biochem. $31: 475-481$.

Johnson, N.C.,J.H.Graham and F.A.Smith (1997). Functioning of mycorrhizal associations along the mutualism-parasitism continuum. New Phytol. 135:575-586.

Kishor, P. B., G. H. Hong, Z. Miao, C. A. Hu and D. P. S. Verma (1995). Overexpression of D1-pyrroline-5-carboxilate synthetase increases Proline production and confers 
osmotolerance in transgenic plants. Plant Physiol. 108:13871394.

Lin, C. C. and C. H. Kao (2000). Effect of $\mathrm{NaCl}$ stress on $\mathrm{H}_{2} \mathrm{O}_{2}$ metabolism in rice leaves. Plant Growth Regul. 30:151 155.

Lowry, O. H., N. R. Roberts, W. S. Mei-Ling and E. J. Crawford (1954). The quantitative histochemistry of brain II. Enzyme measurements. J. of boil Chem. 207:19-37.

MacCue, K. F. and A. D. Hanson (1990). Drought and salt tolerance. Tren in Biotech. 8:358-362.

MacDonald, R. M. and M. Lewis (1978). The occurrence of some acid phosphatases and dehydrogenases in the vesiculararbuscular mycorrhizal fungus Glomus mosseae. New Phytol. 80:135-141.

Mansour, M. M. F., K. H. A. Salama, F. Z. M. Ali and A. F. Aouhadid (2005). Cell and plant responses to $\mathrm{NaCl}$ in $Z e a$ mays L. cultivars differing in salt tolerance. Gen. and Appl. Plant Physiol. 31:29-41.

Meloni, D. A., M. A. Oliva, C. A. Martinez and J. Cambraia (2003). Photosynthesis and activity of superoxide dismutase, peroxidase and glutathione reductase in cotton under salt stress. Environ. and Expe. Bot. 49:69-76.

Morgan, J. M. (1984). Osmoregulation and water stress in higher plants. Annual Review of Plant Physiol. 33:299-319.

Pacovasky, R. S., P. De Silva, M. T. V. Carvalho and S. M. Tsai (1991). Growth and nutrient allocation in Phaseolus vulgaris L. colonized with endomycorrhizae or Rhizobium. Plant Soil 132:127-137.

Phillips, J. M. and D. S. Hayman (1970). Improved procedure for cleaning roots and staining parasitic and vesicular arbuscular mycorrhizal fungi for rapid assessment of infection. Trans. of Brit. Mycol. Soc. 55:158-160.

Porcel, R., J. M. Barea and J. M. Ruiz-Lozano (2003). Antioxidant activities in Mycorrhizal soybean plants under drought stress and their possible relationship to the process of nodule senescence. New Phytol. 157:135-143.

Prochazkova, D., R. K. Sairam, G. C. Srivastava and D. V. Singh (2001). Oxidative stress and antioxidant activity as the basis of senescence in maize leaves. Plant Sci. 161:765-771.

Putter, J. (1974). Peroxidase, pp. 567-1124. In: B. Hu (Eds.). Methods of enzymatic analysis. New York, USA: Academic Press.

Rabie, G. H. and A. M. Almadini (2005). Role of bioinoculants in development of salt-tolerance of Vicia faba plants under salinity stress. Afri. J. of Biotech. 4:210-220.

Reddy, A. R., K. V. Chittanya and M. Vivekanandan (2004). Drought induced responses of photosynthesis and antioxidant metabolism in higher plants. J. of Plant Physiol. 1161:1189-1202.

Rosendal, C. N. and S. Rosendal (1991). Influence of vesicular arbuscular mycorrhizal fungi (Glomus spp.) onion response of cucumber (Cucumis sativus) to salt stress. Enviro. and Exp. Bot. 31:312-317.

Ruiz-Lozano, J. M. and R. Azcon (2000). Symbiotic efficiency and infectivity of an autochthonous arbuscular mycorrhizal Glomus sp. from saline soils and Glomus deserticola under salinity. Mycorrhiza 10:137-143.

Ruiz-Lozano, J. M., R. Azcon and M. Gomez (1996). Alleviation of salt stress by arbuscular-mycorrhizal Glomus species in Lactuca sativa plants. Physiol. Plant. 98:767-772.

Sannazzaro, A. I., R. Oscar, A. Edgardo and M. Ana (2006). Alleviation of salt stress in Lotus glaber by Glomus intraradices. Plant Soil. 285:279-287.

Serrano, R. and R. Gaxiola (1994). Microbial models and stress tolerance in plants. Crit. Rev. of Plant Sci. 13:121-138.

Sheng, M., T. Ming, C. Hui, Y. Baowei, Z. Fengfeng and H. Yanhui (2008). Influence of arbuscular mycorrhizae on photosynthesis and water status of maize plants under salt stress. Mycorrhiza 18:287-296.

Smith, S. E., F. A. Smith and I. Jakobsen (2003). Mycorrhizal fungi can dominate phosphate supply to plants irrespective of growth responses. Plant Physiol. 133:16-20.

Tabatabai, M. A. and J. M. Bremner (1969). Use of p-nitrophenyl phosphate for assay of soil phosphatase activity. Soil Boil and Biochem. 1:301-307.

Vranova, E., D. Inze and F. Van-Brensegem (2002). Signal transduction during oxidative stress. J. of Exp. Bot. 53:12271236.

Wright, D. P., D. J. Read and J. D. Scholes (1998). Mycorrhizal sink strength influences whole plant carbon balance of Trifolium repens L.. Plant Cell Environ. 21:881-891.

Yano-Melo, A. M., O. J. Saggin and L. C. Maia (2003). Tolerance of mycorrhized banana (Musa sp. cv. 'Pacovan') plantlets to saline stress. Agri. Eco. and Environ. 95:343-348.

Zhongqun, H., H. Chaoxinga, Z. Zhibin, Z. Zhirong and W. Huaisong (2007). Changes of antioxidative enzymes and cell membrane osmosis in tomato colonized by arbuscular mycorrhizae under $\mathrm{NaCl}$ stress. Coll and Sur B: Biointer. 59:128-133. 